\title{
Ethnocultural Component of Foreign-Language Education: Innovative Mode
}

\author{
Diana Sabirova \\ Kazan (Volga Region) Federal University, Russian Federation, Institute of International Relations, History and Oriental Studies \\ Email: dianasab@mail.ru
}

\section{Doi:10.5901/mjss.2015.v6n3s1p362}

\begin{abstract}
The article deals with the problem of ethnocultural component of foreign language learning in a secondary school. The educational and methodical courses "Welcome to Tatarstan" and "Tatarstan and the World", which are designed for specialized training of native and foreign languages, are given as an example. The principles of the courses design are the following: technologization, creativity, systemacy, intercourse link, tolerance, etc. It has been proved that one of the necessary conditions to form a view about the studying region is integration of Cultural Studies as a science into the process of foreign language learning.
\end{abstract}

Keywords: sustainable development, global language, ethnocultural component in the content of foreign language education, language education, cross-cultural interaction, native culture.

\section{Introduction}

A language variety and cultural pluralism of the modern world community reflects the movement and transformations in the life of different peoples during the last centuries, reaching its maximum in the XXI century. We witness the process of world globalization, when its driving mechanism is closely connected with expansion of English. Having performed a role of a dominant language English continues to pretend to be a world language. More and more researches have been conducted to find out the role of English in the fast changing world and the methods of teaching it as a means of communication within a multicultural world such as D. Crystal, (1997), J.G. Gebhard (2007), S.Ter-Minasova (2008) and others. However it is impossible to consider this process as well-defined. The process of English speaking and learning by all people is caused by the needs and requirements of the mankind and the necessity of mutual understanding between all people at the universe level. However interaction of cultures and civilizations most often accepts unilateral character that is reflected in a language situation. We have to recognize that English is the only global language which significantly effects a language variety exhaustion.

This study aims to explore the focus on the ethnocultural component in language teaching as well as ethnopedagogical environment of high school.

\section{Literature Review}

Cultural orientation of society represents a very complicated phenomenon that defines the system of values for societies and individuals, bearers of certain culture. National cultures are formed in various natural and social conditions and their direct comparison leads to distortion of authentic representations and formation of stereotypes. On the other hand the comparative studying of cultures is possible only via the mechanism of cultural universals and parameters of each culture based on intern aspect. Thus each native speaker is a bearer of his/her culture and any language acts as a marker of cultural orientation of a society.

Culture belongs to the category of axiomatic concepts which seems to be intuitively transparent. Culture is often described as "a holistic way of life of certain people" representing somehow the way that unites various people and at the same time that causes differences between similar people. In relation to foreign language learning culture begins "when we start speaking a foreign language". Up to the certain start culture is often perceived as something belonging to those people but when we start dealing with them, culture turns (from the category of abstract concepts) into something personal, something that is close to us. It is necessary to agree with the following opinion: "culture begins when you understand that you have language problems. These problems are related to you meaning who you are and what you are." In the context of globalization processes, especially in their cultural segment, this idea gains a new colouring. 
Cultural globalization refers to the intensification and expansion of cultural flows across the globe. The exploding network of cultural interconnections and interdependencies in the last decades has led some commentators to suggest that cultural practices lie at the very heart of contemporary globalization (Steger, 2013).

The thesis of the inseparability of foreign language learning from the culture of the country, its history, sociocultural traditions and peculiarities of the national vision of the world, has long been recognized in the methodology of teaching foreign languages and cultures. Language as communication and culture are products of each other. Communication creates culture: culture is a means of communication. Language carries culture, and culture carries, particularly through orature and literature, the entire body of values by which we come to perceive ourselves and our place in the world (Ngugi wa Thiong'0, 2009).

The concept of language and cultural pictures of the world plays an important role in foreign languages learning. Actually the interferences of native culture complicate communication no less than the ones in a native language. Foreign language learner gets into a new culture and is affected by it. Thus, the secondary picture of the world of the learning language comes into effect. Under the influence of the secondary picture the person changes his worldview. "The person speaking two languages, switching from one language to another, changes the character and the direction of the thoughts and influences its development directly. This effort can be comparable with that a switchman transfers the train to other rails ..." (Potebnya, 1976).

Currently, the educational community in the field of foreign language teaching, recognizes that the traditional focus on the communicative approach has been associated mainly with a linguistic dimension in all its forms and due to it was limited.

The educational potential of a foreign language as the interdisciplinary course promotes introduction of pupils to the world culture and the best understanding of their own culture.

Thus, problems of cross-cultural communication become object of research for: philosophy, sociology, linguistics, theory of communication, sociolinguistics, social and general psychology, public relations, etc. Special importance of cross-cultural communication and, first of all, its defining component as interethnic communication, is found in the curriculum, focusing the main attention on research of an ethnocultural factor for the development of general theory of education and also application of ethnic communication in training of teachers. It is clear that the development of content perception and the elements of foreign culture should be highlighted through the formation of native culture.

The main tool for the implementation of this process is a language as a prerequisite stage in connecting all components of cultural and communicative interaction. In this case, special importance is given to the role of specialist of intercultural communication, mainly foreign language teachers, whose specific professional function is to manage the process of interaction of cultures and their dialogue. Namely they are chief promoters in programming, implementation and ensuring continuity in the preservation of ethnic and cultural traits of the society. Adequate understanding of culture, language and traditions of the country becomes possible only within the process of learning the language and culture of the people. Understanding the world civilization comes via understanding the target language of the country.

According to experts, communication of various languages and cultures representatives is realized with the greatest completeness and efficiency when an important place in the course of teaching a foreign language is given to native culture.

The data about culture, nature and geography of native places significantly supplements the substantial part of communication. Such assessment of an ethnocultural component leads us to the conclusion that this part of national culture is much close and valuable to everyone. We agree with the opinion of A.A. Valeev who declares: "Studying ethnocultural information at the classes of a foreign language has a special pedagogical value because they apply the knowledge from different fields (History, Mythology, Ethics, Psychology, Literature, Music, Cookery, the Fine arts, Toponymics, Geography, Religion) and favourable prerequisites for the development of world outlook are created (Valeev, 2007). Foreign language needs to use such emotional component to enhance learning efficiency

Brooding on the benefits of adjusting to another culture, J.G. Gebhard says: " the benefits are: ..., the possibility of greater success in the workplace, the possibility of establishing meaningful relationships with people from the culture, ..., a deeper understanding of one's own culture, a deeper understanding of oneself' (Gebhard, 2007).

So teachers are urged to play the leading role in implementation of this process. In the world there are over 60 million teachers and each of them is the agent of changes in the system of moral and social values. The former Minister of Education and Science of Great Britain K. Clarke said: "It is vital that the teacher, being competent, effectively performs the work as the children trained by him/her have no one more chance" (Clarke, 1992).

Currently Russia does not have the system of teacher training with a focus on preparing for the work in a multicultural class. The main trends in the development of future teachers education promote tolerance, education, linguistic competence, willingness and involvement in a "dialogue of cultures". 
For this reason, innovations in the system of teacher training is an important part of future education. As part of a special educational programme, the UNESCO Commission on Sustainable Development, requires from Member States to help teachers not only to form the concepts of sustainable development, but also learn how to manage interdisciplinary connections.

An increased interest in cultural problems in the teaching community is a consequence of changes in the leading concepts, reconsideration of cultural experience and socio-economic targets, adjustment of traditional and modern culture-forming goals and objectives of education sector in a changing society.

Research of the ethnopedagogical environment of high school is an integral part of polycultural educational process and the objective requirement of contemporary world. The use of its characteristics in pedagogical process will allow to solve a number of interconnected problems: formation the idea of world cultures variety, educating tolerant relation to cultural distinctions, creating conditions for integration of pupils into cultures of other peoples, creating the spirit of the world, ethnotolerance development, formation of conscious valuable orientations of the personality in relation to cultural heritage, educating respect for history and culture of other peoples, creating polycultural environment as the basis of interaction with elements of other cultures (Dautova, 2003).

Studying the ethnopedagogical environment of the Republic of Tatarstan revealed the following features: polynationality (representatives of more than 100 various ethnoses live here), establishing new schools where students learn national languages (Tatar, Chuvash, Jewish, etc.), quickly changing demographic situation (one of the reasons is increase of refugees numbers), increase of interest in religious holidays, customs (in connection with growth of believers numbers), and also interest in national culture (foundation of national public organizations urged to keep and develop national culture), lack of national conflicts, religion tolerance (different religions of the region), etc. Modern researchers note a great humanistic power of the Russian national culture. The power assumes more close relationships of peoples, their national cultures on the basis of respect for their historical national and universal values. This includes comprehensive support and development of an integrated human society, the union of all people around common values. Humanistic education in Tatar folk pedagogy included such traditions, attitudes towards people as love and care of children, respect for the elderly, respect for women, for the man of labour, hospitality, courtesy, modesty, etc. (Nigmatov, 2007).

\section{Ethnocultural Component in Forming a Multinational Picture of the World}

The major part of mega-language variety is inherent in languages of indigenous people. The knowledge how to support biocultural diversity is coded in the languages of indigenous people therefore the key to the issue how to preserve our planet integrity should be searched in the worldview of these people. More than a decade ago this thesis was presented in the conception "Education for a sustainable development: partnership and cooperation in action" which defined a new paradigm of education, its formation and parameters of its development. In particular it has been noted that "education plays the leading role in the process of inheriting cultural values, behavioural models and national peculiarities. The role of the native languages in the process of knowledge giving is significant. It is especially important for the minor people for preserving their native language, cultural values, traditions and knowledge and for development of abilities demanded to reveal the best in their cultural, economic and natural heritage" (Educating for a sustainable future: commitments and partnerships, 2002).

Modern Russian system of language education is characterized by certain positive crisis caused by changes in the society. The interest in ethnolingvocultural issues among teachers is a consequence of launching new conceptions, reconsideration of cultural experience, changes of social and economic goals that require improvement of the traditional modes and formation of modern developing objectives for education in the changing society (Spradley, 1980). Relevance of the considered issues in the content of foreign language education and nowadays problems are defined by several decisive factors.

Factor 1. Significant ethnic changes in the life of society that took place before the beginning of the XXI century caused a keen interest in national culture of the people, their language, art and traditional values. Therefore the concept 'national picture of the world' as a system of worldviews of certain people of the world is becoming more and more demanded in the fields of science and culture. It means that the practice of creation and application of innovative technologies raises an objective to include the issue 'national picture of the world' in curricula as educational and personal development can be full-fledged only in case of studying traditional values of the ethnos.

Factor 2. The problem of foreign language education got and continues to get more and more valuable sense. This phenomenon grew to the level of planetary value. Openness of the state borders, Russia's participation in globalization processes, mobility expansion, modern information technologies development, understanding a turn of the millennia as a 
milestone demanded new high-quality life standards and caused changes in the life of Russians and in their worldview. "In times when mixture of peoples, languages and cultures reached unprecedented scope, the problem of cultivating tolerance to foreign cultures, awakenings of interest and respect for them, overcoming the feelings of irritation from redundancy, insufficiency or simply dissimilarity of other cultures became the issue of the day." (Ter-Minasova, 2008).

Factor 3. New requirements of social development cause changes in the system of foreign language learning. Foreign language skills adequate to the historical moment became one of the most important conditions for $s$ professional to be compatible in labour market; they show his competence and professional readiness for implementation of the duties at a high technological level. It is important that this process can provide knowledge and form skills and abilities and can have a direct impact on formation of personality (Kramsch, 1993). Innovative approach as a technique of foreign language learning provided a high level of language mastering. High level of language skills makes the projects in the field of teaching prognostic and it is provided by a number of new challenges containing methodical revelations.

Challenge 1. Russian students and graduates are respected for foreign language fluency. However new conditions of languages use show also the shortcomings. Fluency and correctness in lexical and grammatical aspect don't guarantee mutual understanding and, further, productive joint activity in the course of real communication.

In this context the second challenge can be understood better. Despite a huge interest in the research of foreign language cultures, a practical situation, difficulties that pupils and other learners face communicating with representatives of other cultures, make us believe that we are in the very beginning of understanding how purposeful research of things, still applied intuitively, can affect considerably our efforts in the field of foreign language learning.

Challenge 3. Among the objectives of formation and improvement of ethnocultural competence as the indicator of social and moral maturity, first of all, we should take note of mastering the ways of the country and native culture presentation in the conditions of foreign language cross-cultural communication, and also their affinity with new social experience in the use of foreign languages (Elizarova, 2007). It should be highlighted, in our opinion, that it is necessary to work with patriotic motto: "People mould the opinion of their country".

Challenge 4 . We are sure that a foreign language due to the unique educational opportunities has to be considered not as a school class but as a subject. Taking into account this aspect we can say that the real valuable resource of the subject "Foreign language" is concluded in the belief: in what situation the baggage of linguistic knowledge will become necessary for him/her.

The problem is that traditional approaches to foreign language learning do not consider the language as the system of cultural values on the basis of which the behaviour models of the society members are formed as well as their speech activity is caused by cultural traditions.

\section{Research Methodology}

Introduction of an ethnocultural component to the content of foreign language education in the Republic of Tatarstan was caused by insufficient ability of high school pupils to represent national culture and historical heritage of the people at a cross-cultural level. It also defined the main objectives of an ethnocultural component at learning foreign languages among which the most important are the following: readiness of pupils for international cross-cultural communication, to a dialogue of cultures, i.e. ability to analyze, compare political, economic, cultural life of different countries; development of ability to use the knowledge gained at other classes; development of feeling of love for people and the country, pride for the country's achievements.

It is quite real that senior students will learn to represent native culture in the foreign-language environment, to explain the facts of native culture to a foreign guest, and also to define their living position in the Republic of Tatarstan and in the world. The above-named forms of work help them to correct their ideas, assessments and to form a civic position and values.

In this context, the problem of content and methodology of foreign language teaching by means of ethnoregional component becomes very important (McKay S., 2009). In this sense it is important to focus attention once again on implementation of continuity in 'school - higher education institution system' as "today's school students will be university students tomorrow". This interpretation gives a new search power for a language education system in general, and within the designed projects in the Republic of Tatarstan.

While carrying out the research presented in the article we applied a number of research instruments. They were general scientific methods, namely analysis, synthesis, induction, deduction as well as special ones. Practical experience of work with modern textbooks shows that they contain an abundance of factual material on the regional geography, in particular, the countries of the target language. The regional geography of our country, especially of its certain regions is presented in textbooks insufficiently. It is clear that it is impossible to include all information on all regions of the Russian 
Federation and the Republic of Tatarstan. However, the relevance of teaching students to speak on the topics that are close to them, speak on something that is near and dear to them since childhood should be noted; to pick on some things that they are proud of and they are ready to share with a partner in communication.

The analysis of the results of Regional Studies contests organized for school students showed that yesterday's school students - present university students - are not sufficiently provided with the information on local history.

Moreover, foreign language teachers complain about difficulties they face in practice of teaching culture, customs of the native land due to the poor development of this issue and lack of practical guides and material.

Thus, scientific methodical justification and design of programmes on implementation of a regional component in the content of foreign language education gained special importance.

To solve the above-mentioned problems the educational and methodical course "Welcome to Tatarstan" which has universal character was developed for the pupils of 7-9 grades who had begun to study a special course of native and foreign languages. At schools of the Republic of Tatarstan it was successfully launched in 2007.

When the authors designed the course they proceeded from the fact that the regional component in the content of foreign language education can significantly broaden and deepen students' knowledge and understanding the world, along with the development of the native language and culture, and master the skills of using methods of various subjects for regional studies and other research.

Let's consider the principles this guide is based on. They are the following: the principle of systemacy, consisting of a meaningful, structured use of materials on the history, culture, geography, ethnography, art and sport in Tatarstan; technologization principle, involving the use of modern technology, the development of students' creativity, imagination and the ability to develop a situation of linguistic communication in study conditions; the principle of tolerance involves the development of students' ability to understand and accept other cultures as equal partners in interpersonal communication; interdisciplinary principle, according to which the use of the material implies a connection with other subjects of school curriculum (Science, Geography, History, Tatar, Russian, Literature, Biology, Physical education and Music).

Assignments of the chapters are built according to the type of combining different kinds of activities: thematic "tours" in foreign languages, class-show, posters or videos presentation, debates, role activity and "oral journals."

The particular advantage of this pilot programme is a special module on the development of listening comprehension skills "Tatarstan seen by a foreigner." Each chapter is provided with a thematic audio sounded by a native speaker where he shares his experience of living in our country. After listening the students can agree with the opinion of the speaker or present their views on the issues discussed.

A successful approbation of the training manual and the need for further development of a new subject set the task of further development of the programme. In 2010 a textbook "Tatarstan and the World» was published to provide the opportunity of better understanding of the following concepts and categories of multicultural education: national originality, uniqueness, cultural traditions, spiritual culture, national identity and culture of a native land, the common roots of cultures, cultural diversity, differences between cultures, mutual influence of cultures, intercultural communication, culture of interethnic communication, mutual understanding, harmony, solidarity, cooperation, non-violence and others $[7,8,9,10]$. (Ivanova et al., 2010).

This manual, designed for senior students of educational institutions (schools, lyceums, colleges), is built on the basis of communicative-cognitive approach and sets such objectives as developing speaking, reading and writing skills on the basis of local history material and the use of the acquired knowledge in the real world of foreign language communication. The advantage of the textbook is the chapter "Preparing for the Unified State Exam" which, of course, is relevant and useful for both teachers and students.

The texts presented in the manual give an idea of different fields of life of the target language countries (UK, USA, Canada, Australia) as well as the Republic of Tatarstan as a part of the global community. Each module presents an interview with the citizens of Tatarstan on important issues and increases motivation and enhances personal training component.

The exercises system is built in accordance with the requirements of the new standards that suggest self-reliant activities including the analysis and comparison of the social phenomena of English-speaking countries and the Republic of Tatarstan (recruitment, questionnaires, leisure, education system, etc.); use of the Internet search sites; making graphs and charts; learning different styles of writing.

It has great educational value. Based on the principle of humanitarian values, discussion module imparts the pride for the country, the Republic, the region. At the same time, the textbook teaches to see homeland as a part of united polycultural space and the pupils as a part of the world community. The use of ethnocultural component in the process of foreign language learning motivates the interest to learn and brings up independence, responsibility, activity and 
promotes personal development of students.

Successful testing of the programme allowed us to make sure that one of the prerequisites for presenting the information of the region is the integration of Cultural Studies as a science in the process of learning a foreign language. Considerable attention was paid to motivational aspect of student training and it was offered to use an experimental methodology to activate the processes of thinking and speaking.

\section{Conclusion}

Thus, the formation of integrative interdisciplinary modules for foreign language teaching and other subjects in order to strengthen sociocultural orientation of school education and developing innovative aspect; creating manuals on ethnocultural component implementation in the content of foreign language education in the Republic of Tatarstan; launching special courses on regional studies taught in foreign languages; ensuring continuous monitoring of the level of languages use by high school students will help to resolve the problem of updating the content and quality of foreign language education in schools through the expansion of polylinguistic space, to use innovative programmes and develop the integrative model and additional components of language education in future.

The implementation of ethnocultural component in the content of foreign language education in the Republic of Tatarstan will form the ability of secondary school students to represent the national (Tatar and Russian) culture and the cultural and historical heritage of the country and the region at a high level of intercultural communication.

All this defines the main strategies of school language education development in the Republic of Tatarstan. The most important objectives are the following: our students should be well prepared for international and cross-cultural communication, for a dialogue of cultures, that assumes the ability to analyze and compare political, economic and cultural life of different countries; to develop and use the knowledge gained at other courses; the ability to love the country and to be a patriot. We should cultivate the pride for our country's achievements and our students should be wellprepared to present their native land at a world cultural tissue.

\section{References}

Clarke, K. (1992). Speech delivered at North of England Education Conference. L.: HMSO.

Crystal, D. (1997). English as a Global Language. Cambridge: Cambridge University Press.

Dautova, G. (2003). Studies on Ethnopedagogical Environment: the basis of multicultural education. Kazan: TGGPU.

Educating for a sustainable future: commitments and partnerships. (2002). UNESCO.

Elizarova, G. (2007). Culture and language teaching. St.Petersburg.

Gebhard, J.G. (2007). Teaching English as a Foreign or Second Language. (2nd ed.). The University of Michigan.

Ivanova, L., Sabirova, D., Garipova, Zh. (2007). Welcome to Tatarstan! Study guide. Kazan: TAl.

Ivanova, L., Sabirova, D., Garipova, Zh. (2007). Welcome to Tatarstan!. Recommendations for teachers. Kazan: TAl.

Ivanova, L., Sabirova, D., Garipova, Zh. (2007). Welcome to Tatarstan!. Student's workbook. Kazan: TAl.

Ivanova, L., Sabirova, D., Garipova, Zh. (2010). Tatarstan and the World. Study guide. Kazan: TAl.

Kramsch, C. (1993). Context and Culture in Language Teaching. Oxford: Oxford University Press.

McKay, S. (2009). Teaching English as an International language. Oxford: Oxford University Press.

Manfred B. Steger. (2013). Globalization. A very short introduction. Oxford University Press.

Ngugi wa Thiong'o. (2009). From Language to Literature. In Jennifer Jenkins, Global Englishes (pp.206-214). Routledge.

Nigmatov, Z. (2007). Pedagogical culture of the peoples of Russia: humanistic educational potential. In G.Gabdullin (Ed.), Educational potential of national culture (pp. 3-10). Kazan: TGGPU.

Potebnya, A. (1976). Esthetics and poetics. Moscow.

Ter-Minasova, S. (2008). Language and intercultural communication. M.:MSU.

Sabirova, D., Modern Study Guide: implementation of ethno-cultural component in the content of foreign language education. In G.Gabdullin (Ed.), Educational potential of national culture (pp. 336-339). Kazan: TGGPU.

Spradley, J.P. Participant Observation. New York: Holt, Rinehart and Winston, 1980. - 103 p.

Valeev A. Forming ethnocultural values in the language teaching process. In G.Gabdullin (Ed.), Educational potential of national culture (pp. 211-214). Kazan: TGGPU. 